\title{
Alternative methods of scaling Eucalyptus urophylla trees in forest stands: compatibility and accuracy of volume equations
}

\author{
Eder Pereira Miguel ${ }^{(1)}$, \\ Sylvio Péllico Netto ${ }^{(2)}$, \\ Gileno Brito de Azevedo (3), \\ Glauce Taís de Oliveira Sousa \\ Azevedo (3), \\ Alba Valéria Rezende ${ }^{(1)}$, \\ Reginaldo Sérgio Pereira ${ }^{(1)}$
}

\begin{abstract}
This study developed and tested a procedure aimed at reducing the cost of forest stand volume estimation. Using a typical $3 \times 3 \mathrm{~m}$ Eucalyptus urophylla plantation, estimates based on a simplified approach were compared with those of precise but costly reference methods. The simplified approach required measuring the total height and bole diameters up to $2 \mathrm{~m}$ high. The volume of the lower part was estimated using Smalian's formula, while the volume of the upper part was estimated using a simple solid as an approximation. Three typical solids were tested: paraboloid, cone, and neiloid. The approach proposed is non-destructive, because it does not require tree felling, while precise methods are destructive. The operational (traditional) method uses Smalian's formula to measure bole diameter at short intervals over the whole bole, while the precise, more research-suited (reference) method records water displacement (using a xylometer) to accurately measure the volume of each bole section. The reference and traditional methods, as expected, produced very similar results. The approach proposed, using a paraboloid for the upper part, provided results that were not statistically different to the reference values. The volumes estimated by the proposed approach were used to calibrate the Schumacher-Hall function, and the performance of the model was evaluated using the values obtained by the xylometer.
\end{abstract}

Keywords: Forest Inventory, Rigorous Scaling, Dendrometric Prototype, Volume Equation, Modeling

the diameters $d_{0.5 n}$ and $d_{1,30}$ to express the bole form of a tree. He applied this concept to the silver fir (Abies alba Mill.), which triggered numerous subsequent research studies on tree forms in Europe. The analytical solution for estimating the form factor as a function of a form quotient $q_{i}$ and a tree height $h$ was first proposed by Schiffel (1902), using the following equations (eqn. 1):

$$
\begin{aligned}
& v=d^{2} h\left(a_{0} q+\frac{a_{1}}{q h}+a_{2}\right) \\
& v=\beta_{1} d^{2} h q+\beta_{2} d^{2} q^{-1}+\beta_{3} d^{2} h
\end{aligned}
$$

where $v$ is the tree volume, $d$ is the diameter at breast height (DBH), $h$ is the tree height, $a_{\mathrm{i}}$ and $\beta_{\mathrm{i}}$ are coefficients of the model, and $q$ is the proposed form quotient.
Because of its practical applications to various European forest species, it stimulated the development of other formulations and conceptions of volumetric equations. Soon after, the Swedish researcher Höjer presented an analytical form for a forest species (Höjer 1903). Later, Prodan (1965) presented an evolutionary synthesis of form quotients.

The sectioning of tree boles into different geometric bodies has been previously considered since the first biometric studies, and is an important approach for obtaining their respective volume (Smalian 1837, Riecke 1840, Breymann 1868, Simony 1904).

Hohenadl (1922) reported that dominant trees have higher relative increments at the bottom (i.e., in the neiloid segment) to ensure a better balance of trunk weight. He concluded that in these cases the vol(1891), who is considered the first person to introduce the form quotient between

(1) Department of Forest Science, University of Brasília (UnB), Campus Darcy Ribeiro, Brasília, CEP 70910-900 (Brazil); (2) Department of Forest Science, Federal University of Paraná (UFPR), Av. Prof. Lothário Meissner, 900 Campus III UFPR - Botanical Garden, Curitiba, CEP 80210-170 (Brazil); (3) Federal University of Mato Grosso do Sul (UFMS), Campus Chapadão do Sul, Rod. MS 306, Km 105, CXP 112, Chapadão do Sul/MS, CEP 79560-000 (Brazil)

@ Eder Pereira Miguel (miguelederpereira@gmail.com)

Received: Jun 27, 2016 - Accepted: Jan 09, 2018

Citation: Miguel EP, Péllico Netto S, Azevedo GB, Azevedo GTOS, Rezende AV, Pereira RS (2018). Alternative methods of scaling Eucalyptus urophylla trees in forest stands: compatibility and accuracy of volume equations. iForest 11: 275-283. - doi: 10.3832/ifor2155-011 [online 2018-03-29]

Communicated by: Davide Travaglini 
ume is associated with genetic variables, as well as environmental and silvicultural practices. Larson (1963) stated that tree form varies depending on edaphic conditions, climate change, the silvicultural practices conducted in forest stands, and the sociological position of each tree. It also varies according to the age of the forest stand, either as a natural evolutionary phenomenon, or due to the competitive status of each tree in relation to its closest neighbors. Row \& Guttenberg (1966) recommend that for better detection of variations in tree stem form at least three distinct sections should be taken. In the 1960 , several other important studies on tree form were published, including a proposal for the so-called "taper function" (Larson 1963, Prodan 1965, Grosenbauch 1966, Schöpfer 1966, Kozak et al. 1969).

It was assumed in the case of sectioned stems that their forms could be represented complementarily as geometrical solids: a neiloid at the base, a paraboloid in the central part, and a cone at the terminal part (Row \& Guttenberg 1966, Loetsch et al. 1973). There have even been proposals to use different mathematical functions for each segment. In his study on Picea excelsa, Roiko-Jokela (1976) retained the three segments, but used a hyperbola to describe the neiloid, a logarithmic function to describe the paraboloid, and a straight line to describe the cone. There are still researchers who separate the stem into more than three sections, but such approaches have increased the difficulty of adjusting the mathematical functions used for their description (Preußner 1974, Liu 1980, Husch et al. 1983).

In forest inventories, the volume of an individual tree is usually obtained by indirect techniques such as volumetric equations, taper functions, and the form factor (Grosenbauch 1966, Loetsch et al. 1973, Husch et al. 1983, Schröder et al. 2013, Machado \& Figueiredo Filho 2014, Murta Júnior et al. 2015), which are derived from direct measurements of the volumes of some trees in the forest stand. Volumetric equations, which are derived from the adjustment of regression models and are based on existing relationships between volume and easily measurable variables in the field (e.g., tree diameter and height), are the most commonly used procedures to estimate volume (Akindele \& LeMay 2006, Batista et al. 2014). They have satisfactory efficiency (Azevedo et al. 2011, Schröder et al. 2013), and are in current, well-known volume models (Spurr 1952, Prodan 1965, Loetsch et al. 1973).

Of the several methods for measuring tree volume, water displacement (using a xylometer) is the only technique that provides the true volume, and is usually used as a reference in accuracy evaluations of other methods (Machado et al. 2006, Akossou et al. 2013, Machado \& Figueiredo Filho 2014). However, due to the operational limitations inherent in this method, the (true) volume of individual trees has been estimated with good accuracy by rigorous scaling (measurement of the diameter and height along the bole) using mathematical expressions (e.g., Smalian, Huber, Newton, Hohenadl, and Pressler, among others). This requires taking measurements of felled trees, or the rigorous volume estimation of standing trees using specialized equipment. In Brazil, Smalian's method has traditionally been used for most forest surveys, by normally defining short sections up to $2 \mathrm{~m}$ in height and 1 or $2 \mathrm{~m}$ sections for the rest of the trunk, more for convenience than for any accuracy reasons (Machado \& Figueiredo Filho 2014).

Rigorous scaling is normally performed with sample trees felled in plots of the forest inventory or in close areas, an activity that is not part of the yearly routine of measurements in the forest inventory. In addition, there are situations where it is impossible or impractical to obtain scaling data that provide precise volume estimates for the remaining trees in the stand. Therefore, the use of alternative methodologies for scaling in forest inventories could increase the rate of data collection, reduce costs, and minimize technical and operational difficulties (Andrade et al. 2014). Preferably, this should be conducted without felling trees (non-destructive methods) using complex equipment to measure only a few bole diameters.

One alternative would be to measure a few diameters of standing trees up to a height that is easily measurable, assuming that the stem from that point to the top can be treated as a single section. In this way, tree scaling would be optimized, because the volume up to an easily measurable height is directly obtained using a traditional tree-scaling method. From that point up, the volume is estimated using a geometrical solid to express the stem form, i.e., using dendrometric prototypes (paraboloid, cone, or neiloid). This methodological proposal is justified, because in commercial plantations tree boles tend to resemble these geometrical forms. However, the lower part usually shows a more irregular form (Machado et al. 2004). Such a configuration using dendrometric prototypes must be conducted with great accuracy, because the lower part accounts for the greatest part of the overall volume (Batista et al. 2014).

Although the volumes of a cone and neiloid can be used to generate a wide variety of shapes, the volume of a paraboloid is the most appropriate for this modeling. If its base is considered at a height of $2 \mathrm{~m}$ for obtaining the volume, then (eqn. 2):

$$
g_{2}=\frac{1}{4} \pi d_{2}^{2}
$$

where $g_{2}$ is the cross-sectional area measured at a height of $2 \mathrm{~m}$ on the stem and $d_{2}$ is the diameter measured at $2 \mathrm{~m}$.

For the paraboloid, the volume and the form factor are defined in eqn. 3 and eqn. 4, respectively:

$$
\begin{aligned}
& v_{2}=g_{2} h_{2} f_{2} \\
& f_{2}=\frac{1}{d_{2}+1}
\end{aligned}
$$

where $v_{2}$ is the volume of the paraboloid, $g_{2}$ is the cross-sectional area measured at $2 \mathrm{~m}$ above the ground, $h_{2}$ is the height of the bole above $2 \mathrm{~m}, f_{2}$ is the form factor of the bole measured above $2 \mathrm{~m}$ and $d_{2}$ is the diameter measured at $2 \mathrm{~m}$.

The development of the paraboloid form depends on $f_{2}$, as defined in eqn. 4. We initially decided to use Apollonius's paraboloid (form factor equal to 0.5) to scale Eucalyptus urophylla trees without felling them. In addition, we compared the results obtained by rigorous scaling using the Smalian's method, which is traditionally applied to measure tree volumes in commercial plantations of Eucalyptus in Brazil (Soares et al. 2010), with those obtained using a xylometer. We also evaluated the effects of different scaling methods on the accuracy of volumetric equations adjusted to the forest stand.

Based on the above considerations, we formulated the following hypotheses: (1) the estimated $E$. urophylla tree volume, as composed of a base evaluated using the Smalian's method with detailed measurements taken up to a height of $2 \mathrm{~m}$ and an upper part estimated as a basic paraboloid, is similar to that obtained using a xylometer, or the volume obtained by Smalian's method applied to the entire stem; (2) the volume function calibrated with the values estimated by the simplified approach would approximate very well to the reference (xylometer) estimates.

\section{Material and methods}

\section{Study area}

The study was conducted in a 7-year-old E. urophylla S. T. Blake plantation spaced at $3 \times 3 \mathrm{~m}$ in Rio Verde, southwest Goias state, Brazil, which belongs to the agro-industrial cooperative of farmers of that region (COMIGO). The plantation is at an average altitude of $700 \mathrm{~m}$ a.s.l. at $18^{\circ} 00^{\prime} 45^{\prime \prime}$ to $18^{\circ}$ $01^{\prime} 45^{\prime \prime} \mathrm{S}$ and $50^{\circ} 52^{\prime} 45^{\prime \prime}$ to $50^{\circ} 53^{\prime} 15^{\prime \prime} \mathrm{W}$. According to the Köppen classification, the climate of the region is Aw (tropical humid), and is characterized by having two well-defined seasons: dry in the autumn and winter, and wet with heavy rain in the spring and summer. The annual average air temperature ranges from 20 to $25^{\circ} \mathrm{C}$, and the rainfall is between 1200 to $1500 \mathrm{~mm}$, with an annual average of around $1300 \mathrm{~mm}$ (Siqueira Neto et al. 2011).

The dominant soils have B Latosol and A moderate horizons and a clay texture, and are classified by EMBRAPA (2013) as Red Latosols, corresponding to Red Oxisols in the USDA Soil Taxonomy (Soil Survey Staff 2010) and Ferralsols in WRB (IUSS Working Group 2010). 
Data

One hundred and fifty trees of different diameter classes were randomly selected in the population and cut down for the present study. DBHs were measured using a caliper, and ranged from 7.2 to $20.6 \mathrm{~cm}$. The total heights of standing trees were measured using a Vertex ${ }^{\oplus}$ hypsometer, while those of felled trees were measured using a tape measure, and ranged from 14.2 to $30.6 \mathrm{~m}$.

After measuring the DBHs and total heights, a rigorous scaling of each tree was performed to obtain its actual volume. This was conducted using three non-destructive methods by scaling standing trees and two destructive methods by cutting trees down.

The scaling of standing trees up to a stem height of $2 \mathrm{~m}$ was performed using the Smalian's method and by taking detailed measurements. From that height up, the remaining part of the stem was assumed to include three distinct dendrometric prototypes, i.e., a paraboloid, a cone, and a neiloid (Fig. 1). The diameters of boles with bark were measured at $0.1,0.3,0.5,0.7$, $0.9,1.1,1.3$, and $2.0 \mathrm{~m}$ above ground level, and from that height up, at every $1 \mathrm{~m}$ up to a stem diameter of $4 \mathrm{~cm}$ (commercial). The three non-destructive methods are hereafter referred to as Smalian + Paraboloid, Smalian + Cone, and Smalian + Neiloid.

After taking measurements of the standing trees, they were cut at $0.1 \mathrm{~m}$ above the ground. The length of the upper part was calculated by taking the difference between the total and commercial heights.

When using Smalian's method (Machado \& Figueiredo Filho 2014) on each felled tree, volumes were obtained for all inter- mediate sections along the tree bole, i.e., between $0.1 \mathrm{~m}$ above the ground up to the minimum merchantable diameter $(4 \mathrm{~cm})$.

Another destructive method used was the xylometer, by which the volume was obtained by sectioning each tree and immersing the sections (small logs) in a container with water. The water volume displaced corresponded to the true wood volume (Archimedes' principle). The xylometer used in this study was similar to the one described by Machado et al. (2006), and was made of two connected drums (total capacity of 200 L) with leveling screws on the bottom and a graduated $\left(\mathrm{dm}^{3}\right)$ external ruler for measuring the displaced water volume. According to Machado \& Figueiredo Filho (2014), the xylometer method has been used as a reference to evaluate the accuracy of other techniques for obtaining the real volume. It has the advantage of being independent of trunk form, and eliminates some measuring errors, as the diameters and lengths of sections along the stem are not measured.

When comparing the tree-scaling methods (destructive and non-destructive), stump volume (o to $10 \mathrm{~cm}$ ) and the upper part's volume were not included in the evaluation methods. These volumes were not included when using the xylometer because the stump and the upper part of trees are usually left in the forest stand after cutting.

\section{Evaluation of tree-scaling methods}

The efficacy of the different tree-scaling methods in obtaining the volumes of individual trees was evaluated using a KruskalWallis test $(a=0.05)$, with the volume obtained by the xylometer used as a refer- ence. Five treatments (Xylometer, Smalian, Smalian + Paraboloid, Smalian + Cone, and Smalian + Neiloid) and 150 replications (trees rigorously scaled) were included. The analyses were conducted using the software Sbpank version 2.17c (Hammer et al. 2001).

The volumes obtained by the different scaling methods were evaluated $a$ posteriori by the aggregate difference (AD), which is the difference between the sum of the volumes obtained by the xylometer and the volumes obtained by the other scaling methods (Machado et al. 2008). We also investigated the distribution of residuals, which indicates under- or overestimates when using each of the proposed scaling methods.

\section{Model adjustment and validation}

Volume data obtained by the xylometer and the other scaling methods, which were not statistically different, were used to adjust the volumetric model of Schumacher \& Hall (1933) to assess the influence of each method on the accuracy of the estimates obtained by the volumetric equations. To achieve this objective, the trees were randomly grouped into two datasets: one for model adjustment using data from each scaling method (100 trees), and the other for model validation (50 trees).

The Schumacher \& Hall model was adjusted using the software STATISTICA ${ }^{\circledast}$ ver. 7.0 (Statsoft Inc., Tulsa, OK, USA) with the Levenberg-Marquardt algorithm and 1000 iterations. The quality of the adjustment was evaluated by the significance of the regression and its parameters $(\alpha=0.05)$, and by the following measures of precision: coefficient of determination $\left(R^{2}\right)$, residual stan-

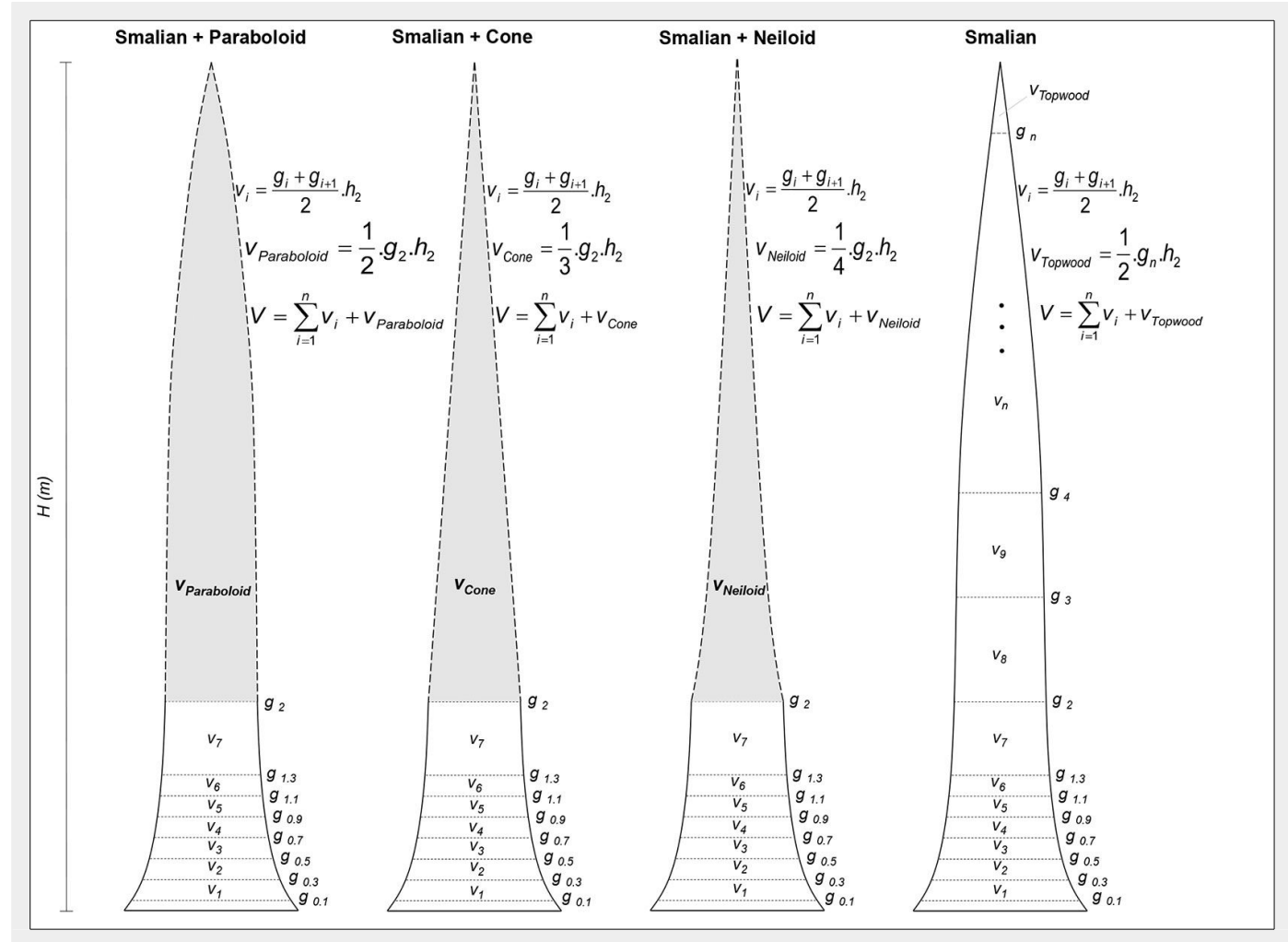

Fig. 1 - Schematic representation of tree scaling using three non-destructive methods and the traditional Smalian's method (destructive). The nondestructive methods were Smalian + Paraboloid, Smalian + Cone, and Smalian + Neiloid. (L): length of the section $(\mathrm{m})$; $(H)$ : total height $(m) ;\left(g_{i}\right)$ : sectional area at height $i$ $\left(\mathrm{m}^{2}\right) ;\left(v_{\mathrm{i}}\right)$ : volume of section $i\left(\mathrm{~m}^{3}\right)$; $\left(v_{\text {Paraboloid }}\right)$ : volume of paraboloid $\left(\mathrm{m}^{3}\right)$; $\left(v_{\text {cone }}\right)$ : volume of cone $\left(\mathrm{m}^{3}\right)$; $\left(v_{\text {Neiloid }}\right)$ : volume of neiloid $\left(\mathrm{m}^{3}\right)$; ( $\left.v_{\text {Ponta }}\right)$ : tip volume $\left(\mathrm{m}^{3}\right) ;(\mathrm{v})$ : volume of the tree $\left(\mathrm{m}^{3}\right)$. 
Tab. 1 - Performance of different scaling methods to obtain Eucalyptus urophylla tree volumes. Means followed by the same letter in a column did not significantly differ ( $p>0.05)$ after Kruskal-Wallis test. (AD): aggregate difference.

\begin{tabular}{|c|c|c|c|c|c|c|}
\hline \multirow{2}{*}{ Treatment } & \multirow{2}{*}{$\mathrm{n}$} & \multicolumn{3}{|c|}{ Volume $\left(\mathrm{m}^{3}\right)$} & \multirow{2}{*}{$\begin{array}{l}A D \\
\left(m^{3}\right)\end{array}$} & \multirow{2}{*}{$\begin{array}{l}A D \\
\text { (\%) }\end{array}$} \\
\hline & & Mean & Min & Max & & \\
\hline Xylometer & 150 & $0.2174^{\mathrm{a}}$ & 0.0314 & 0.4832 & - & - \\
\hline Smalian & 150 & $0.2165^{a}$ & 0.0315 & 0.4806 & 0.1306 & 0.40 \\
\hline Smalian + Paraboloid & 150 & $0.2190^{\mathrm{a}}$ & 0.0294 & 0.4991 & -0.2438 & -0.75 \\
\hline Smalian + Cone & 150 & $0.1577^{\mathrm{b}}$ & 0.0223 & 0.3548 & 8.9549 & 27.46 \\
\hline Smalian + Neiloid & 150 & $0.1271^{c}$ & 0.0188 & 0.2826 & 13.5543 & 41.56 \\
\hline
\end{tabular}

(a)

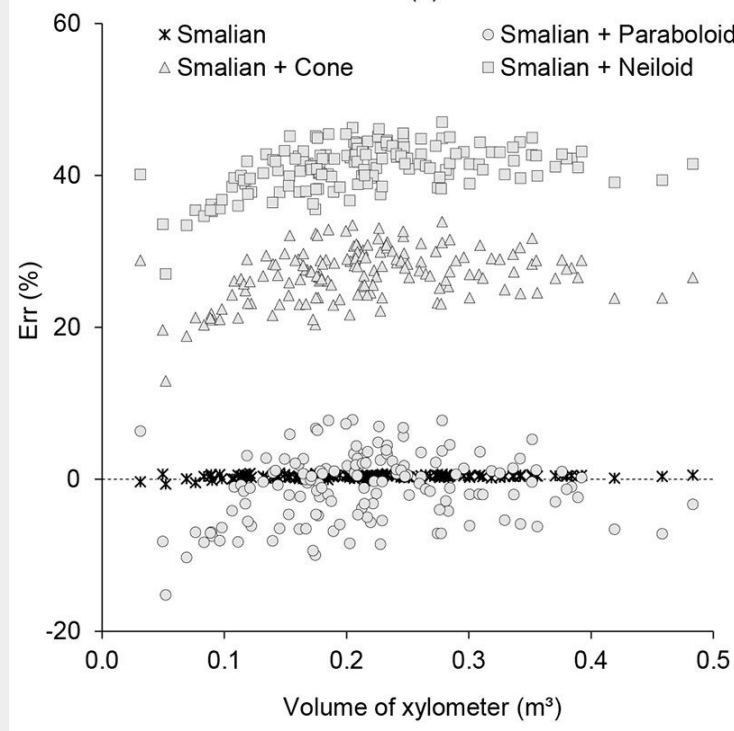

(b)

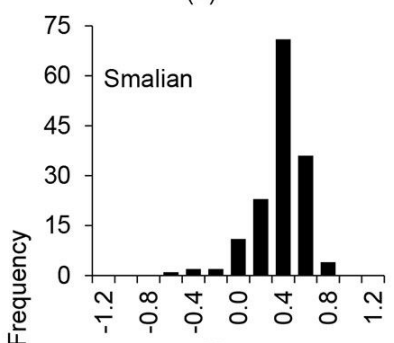

(d)

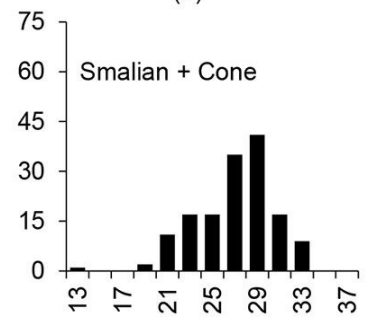

(c)

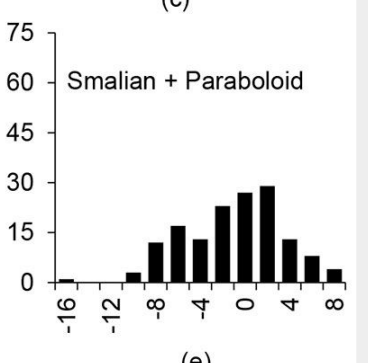

(e)

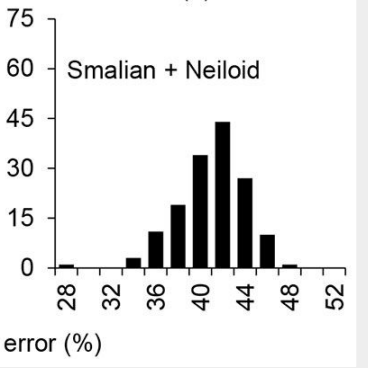

Fig. 2 - Graphical analysis of errors observed in Eucalyptus urophylla volume estimation. Different tree-scaling methods were used and compared with the xylometer method. Individual error distribution (a) and histograms of errors (b, c, d, and e). dard error as a percentage ( $\mathrm{S}_{\mathrm{yx}} \%$ ), and graphical analysis of the residuals (Draper \& Smith 1998), in addition to investigating the correlation between observed and estimated values (Piñeiro et al. 2008).

For model validation, a comparison was made of the volumes estimated by each adjusted equation and those obtained by the xylometer using the Kruskal-Wallis test $(\alpha=0.05)$. The Pearson's correlation coefficient $(r)$ between the values observed (xylometer) and those estimated by the other methods ( $\mathrm{S}_{\mathrm{yx}} \%$ and $\mathrm{AD}$ ) were assessed, in addition to the graphical analysis of the errors.

\section{Results}

Tab. 1 shows that the estimates of tree volumes in the E. urophylla stand differed between the different tree-scaling meth- ods. Traditional tree scaling using the Smalian's method (destructive), and scaling using the Smalian + Paraboloid non-destructive method proposed in this study, were statistically similar to the xylometer method ( $p=0.8663$ and $p=0.9549$, respectively), which is considered a reference for comparison with other methods. However, the average tree volumes estimated by the other two non-destructive rigorous scaling methods (Smalian + Cone and Smalian + Neiloid) did significantly differ from the mean volumes obtained by the xylometer method $(p<0.0001)$, the traditional Smalian's scaling method $(p<0.0001)$, and the Smalian + Paraboloid method $(p<0.0001)$. In general, the Smalian + Cone and Smalian + Neiloid methods tended to underestimate the volume obtained by the xylometer method by more than $27 \%$, and signifi-

Tab. 2 - Volumetric equations with their respective statistics of adjustment, obtained from data applied to different rigorous tree-scaling methods (Xylometer, Smalian, and Smalian + Paraboloid) on Eucalyptus urophylla trees. (V): volume $\left(\mathrm{m}^{3}\right) ;(\mathrm{DBH})$ : diameter at breast height $(\mathrm{cm})$; $(\mathrm{H})$ : total height $(\mathrm{m}) ;\left(\mathrm{R}^{2}\right)$ : coefficient of determination; ( $\left.\mathrm{S}_{\mathrm{yx}} \%\right)$ : residual standard error (\%).

\begin{tabular}{llcc}
\hline $\begin{array}{l}\text { Tree-Scaling } \\
\text { Method }\end{array}$ & Volumetric Equation & $\mathbf{R}^{2}$ & $\mathrm{~S}_{\mathrm{yx}} \%$ \\
\hline Xylometer & $\mathrm{V}=0.000020 \cdot \mathrm{DBH}^{1.588006} \cdot \mathrm{H}^{1.539417}$ & 0.9717 & 6.64 \\
Smalian & $\mathrm{V}=0.000022 \cdot \mathrm{DBH}^{1.608694} \cdot \mathrm{H}^{1.495780}$ & 0.9721 & 6.59 \\
Smalian + Paraboloid & $\mathrm{V}=0.000019 \cdot \mathrm{DBH}^{1.756855} \cdot \mathrm{H}^{1.419518}$ & 0.9800 & 5.21 \\
\hline
\end{tabular}

cantly differed between themselves ( $p<$ 0.0001).

A graphical analysis of the errors associated with the results of the individual tree volumes obtained by each tree-scaling method in relation to the xylometer method showed that the traditional (destructive) Smalian's technique had the greatest accuracy (-0.64\% to $0.82 \%)$, despite having a slight tendency to underestimate the volume (Fig. $2 a$ and Fig. 2b).

The three non-destructive methods proposed in this study exhibited more expressive dispersion of errors (Fig. 2a). The Smalian + Paraboloid method, with errors varying from $-15.21 \%$ to $7.83 \%$, had a slight tendency to overestimate the volume (Fig. $2 a$ and Fig. 2C), whereas the Smalian + Cone (Fig. $2 a$ and Fig. 2d) and Smalian + Neiloid methods (Fig. 2a and Fig. 2e) underestimated the tree volumes by $12.97 \%$ to $33.93 \%$ and $27.06 \%$ to $47.01 \%$, respectively.

We applied the volume data obtained by the destructive and non-destructive scaling methods to adjust the volume equations, using the Schumacher \& Hall model for each method. The volume equations obtained by the tree scaling methods that were compatible with the xylometer method (Smalian and Smalian + Paraboloid) had similar statistics for adjustment and accuracy, with a relatively high value of $\mathrm{R}^{2}$ $(>0.97)$ and a relatively low value of $\mathrm{S}_{\mathrm{yx}} \%$ $(<6.65 \%$ - Tab. 2$)$. In addition, they were 
Fig. 3 - Correla-

tions between

observed and

estimated vol-

umes and the dis-

tribution of resid-

uals from volu-

metric equations.

The following

methods were

used: xylometer

( $a$ and d), Smalian

(b and e), and

Smalian + Parabo-

loid (c and $f$ ).
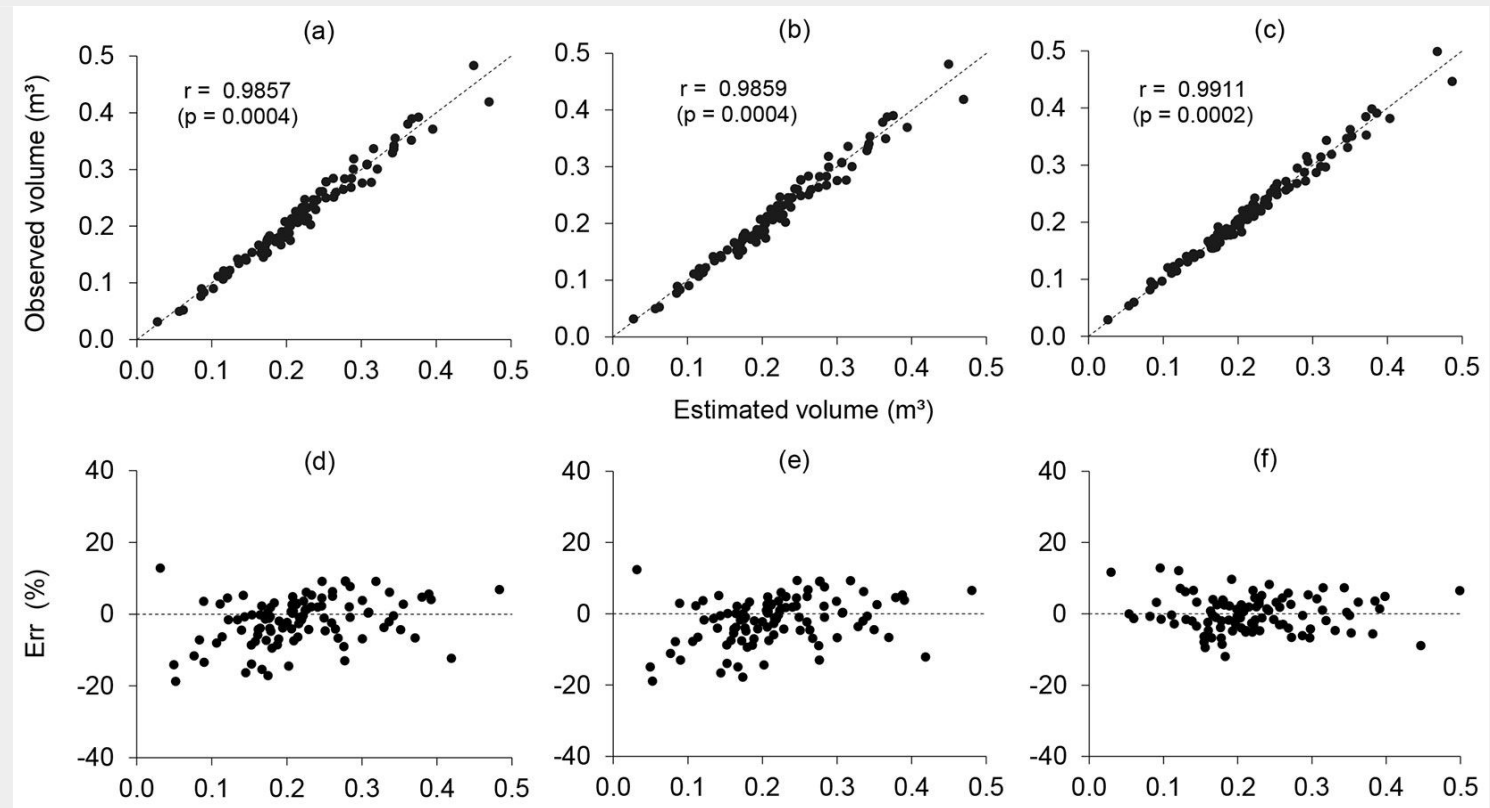

(e)
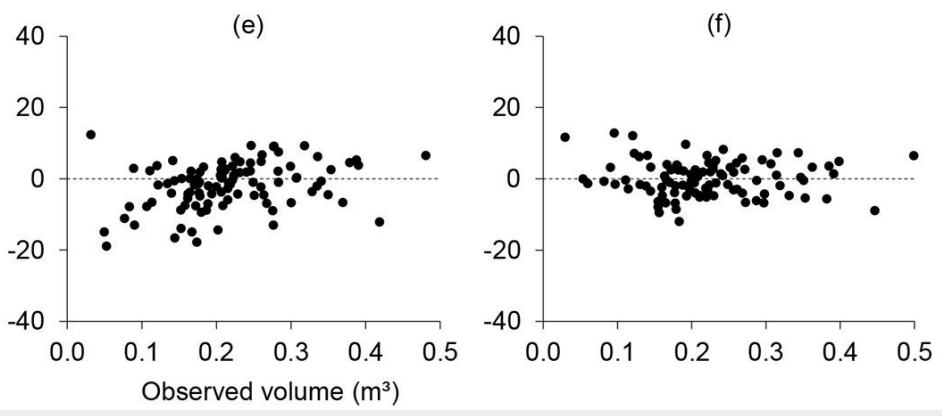

Fig. 4 - Correlations between true (xylometer) and estimated volumes, and the distribution of residuals from volumetric equations. The following methods were used: xylometer ( $a$ and $d$ ), Smalian (b and
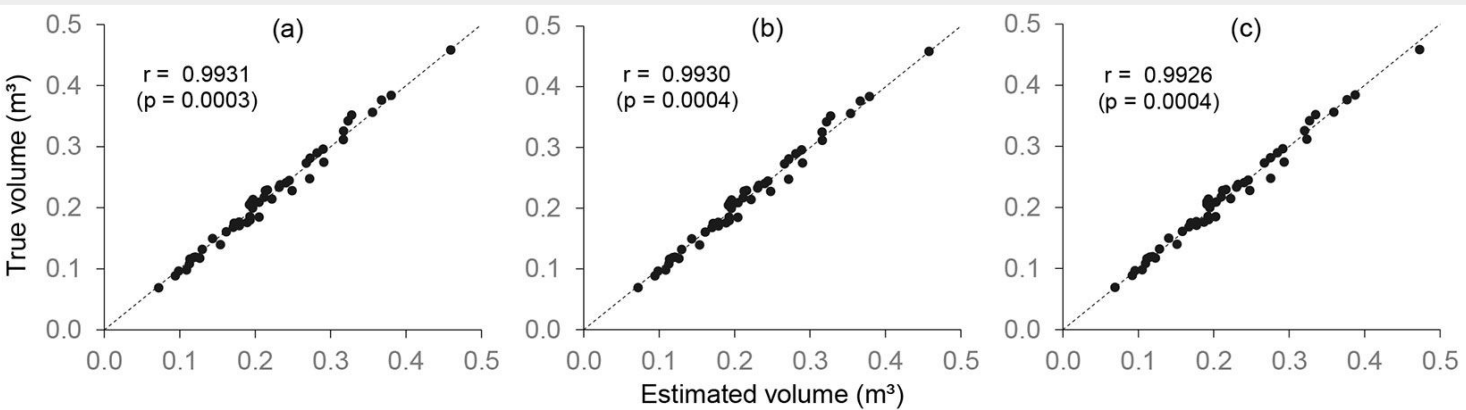

(d)

e), and Smalian + Paraboloid (c and

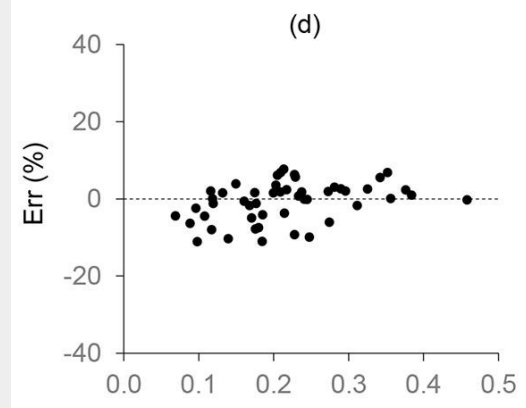

(e)

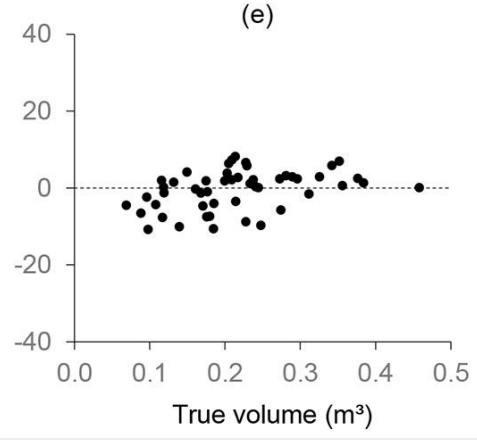

significant for all of the coefficients of the satisfactory distributions of residuals with tistically different to the true volume obequations $(p<0.0001$ ). All of the equations errors of between $-18.91 \%$ and $12.89 \%$ (Fig. tained by the xylometer method ( $p>0.8523$ predicted strong correlations between the 3d, Fig. 3e, and Fig. 3f).

xylometer values and the estimated values

A validation of these equations revealed - Tab. 3). The three equations provided accurate volume estimates $\left(\mathrm{S}_{\mathrm{yx}} \%<5 \%\right.$, with (Fig. 3a, Fig. 3b, and Fig. 3c), and provided that the estimated volumes were not sta- relatively strong correlations between the

Tab. 3 - Performance of volumetric equations in estimating Eucalyptus urophylla tree volumes in relation to a (reference) volume obtained using the xylometer method. Means followed by the same letter did not significantly differ ( $p>0.05)$ after Kruskal-Wallis test. $(n)$ : number of trees; $(A D)$ : aggregated difference; $\left(S_{y x} \%\right)$ : residual standard error $(\%)$.

\begin{tabular}{|c|c|c|c|c|c|c|c|}
\hline \multirow{2}{*}{ Treatment } & \multirow{2}{*}{$\mathrm{n}$} & \multicolumn{3}{|c|}{ Volume $\left(\mathrm{m}^{3}\right)$} & \multirow{2}{*}{$\begin{array}{l}A D \\
\left(m^{3}\right)\end{array}$} & \multirow{2}{*}{$\begin{array}{l}A D \\
(\%)\end{array}$} & \multirow{2}{*}{$\mathrm{S}_{\mathrm{yx}} \%$} \\
\hline & & Mean & Min & Max & & & \\
\hline Xylometer & 50 & $0.2161^{\mathrm{a}}$ & 0.0691 & 0.4581 & - & - & - \\
\hline Xylometer equation & 50 & $0.2161^{\mathrm{a}}$ & 0.0721 & 0.4593 & 0.0011 & 0.01 & 4.91 \\
\hline Smalian equation & 50 & $0.2154^{\mathrm{a}}$ & 0.0722 & 0.4577 & 0.0337 & 0.31 & 4.97 \\
\hline (Smalian + Paraboloid) equation & 50 & $0.2160^{\mathrm{a}}$ & 0.0692 & 0.4731 & 0.0078 & 0.07 & 4.94 \\
\hline
\end{tabular}


true values (xylometer) and the estimates (Fig. 4a, Fig. 4b, and Fig. 4c). The AD between the true values and the estimated ones was less than $0.31 \%$ (Tab. 3), and the distribution of residuals had errors of between $-11.30 \%$ and $9.58 \%$ (Fig. 4d, Fig. 4e, and Fig. 4f), with no bias.

\section{Discussion}

Rigorous scaling using the traditional Smalian's method resulted in less variation in tree volume than that obtained by the xylometer method, so had better precision, although they were not significantly different. This outcome was expected, because the method is also used as a reference when obtaining wood volume in routine forest inventories in Brazil (Machado et al. 2005, Machado \& Figueiredo Filho 2014). Smalian's method is used in both native forests and plantations (Soares et al. 2010); however, it often gives less satisfactory results than other scaling methods, such as the traditional formulas of Huber and Newton (Figueiredo Filho et al. 2000, Machado et al. 2006). Smalian's method gives its worst estimates when combined with long and large sections, a problem that did not occur for the shorter sections used in this study (Machado et al. 2006, Machado \& Figueiredo Filho 2014).

Although the Smalian + Paraboloid method gave a higher dispersion of errors than the traditional Smalian's scaling method, the volumes obtained were concentrated around the true mean (xylometer). Around $99 \%$ of the volumes obtained by this method had errors of between $-10 \%$ and $10 \%$. However, when considering the average volume $(n=150)$, this method provided similar volumes to those obtained by the Smalian and xylometer methods. It overestimated the volume by less than $1 \%$, and is therefore considered quite accurate.

The results indicate that the part of the bole above a height of $2 \mathrm{~m}$ had the greatest similarity to the paraboloid form, which would naturally provide a larger volume than those obtained by the cone and neiloid forms, and explains the underestimations obtained when using these two forms to describe the tree bole. To assess the stem profile, three randomly selected trees (small, medium, and large) in the forest stand were measured to ascertain whether several geometrical solids were expressed in their forms, as described by Van Laar \& Akça (2007). We found that the paraboloid was the prototype that best approximate to the form of the stem above a height of $2 \mathrm{~m}$. Tree scaling using Smalian's method had less variation over the dispersion of errors (Fig. 2), because the large number of sections measured along the bole allowed the capture of possible variations in the form of the stem profile.

The adjustment of the Schumacher \& Hall model provided accurate equations to estimate tree volumes, irrespective of the tree-scaling method (Xylometer, Smalian, or Smalian + Paraboloid) used. When the resulting equations were applied to an independent dataset that was not used in the adjustment of the models (validation), they all yielded similar estimates of the true (xylometer) volume. This confirms that the method proposed (Smalian + Paraboloid) was efficient in obtaining the volume, which is a variable required for the adjustment of volumetric models.

The use of the Smalian + Paraboloid method is a promising alternative for the inventories of other forest species, such as pine and acacia. It allows to take advantage of plot randomness in the inventory area to collect representative data that will be used in the adjustment of volumetric models capable of generating precise estimates of the volumes of other trees in the forest stand. By adopting this method, the gathering of all necessary information can be performed simultaneously with plot measurement, and diameters can be measured in a few sample trees up to a height of $2 \mathrm{~m}$, thereby avoiding tree felling or the use of specialized equipment to measure standing trees.

This procedure also allows a reduction in the number of diameters measured along the bole when compared with traditional tree scaling. In this study, traditional tree scaling by the Smalian's method required the measurement of 28 diameters (on average) along the bole of each tree, while the Smalian + Paraboloid method required only 8 diameters, enabling us to reduce the number of measurements by $71 \%$. Therefore, the use of this method may improve data collection and reduce the costs of forest inventory activities. In addition, it offers an alternative for obtaining tree volumes where tree scaling using destructive methods is impractical.

However, some care must be taken when using this method, particularly regarding tree form. Indeed, according to Soares et al. (2011), bole volume is strongly correlated with its form. Several factors may affect tree form, including species, site, silvicultural practice, age, and genetic expression, among others (Van Laar \& Akça 2007, Batista et al. 2014). Tree form in the population studied was considered similar to an Apollonius's paraboloid. However, it is important to note that the tree boles of other Eucalyptus stand, or of any other species, can resemble alternative forms of a paraboloid, or even of other geometrical solids (dendrometric prototypes). Therefore, it is recommended to examine each specific case, and to adopt the most appropriate method for calculating the volume. In this study, we proposed taking an average tree of the forest stand and obtaining its bole volume $\left(v_{n}\right)$ by applying Smalian's method for a neiloid up to a height of $2 \mathrm{~m}$. Above that height, a generic paraboloid should be used as defined in eqn. 3 (i.e., $v_{2}=g_{2} h_{2} f_{2}$ ). After sectioning the tree, we can obtain its volume using a xylometer in such a way as to provide the volumes for the neiloid sec- tion $\left(v_{\mathrm{xn}}\right)$ and for the bole above $2 \mathrm{~m}\left(v_{\mathrm{x} 2}\right)$ separately. If it is assumed that $v x_{2}$ is equivalent to that of a cylinder that has a constant cross-sectional area $g_{x c}$ and height $h_{x 2}$, then we have $v_{\mathrm{x} 2}=g_{\mathrm{xc}} h_{\mathrm{x} 2}$. Assuming that we wish to set the paraboloid such that the two volumes are equal (i.e., $v_{\mathrm{x} 2}=v_{2}$ ), then we have $h_{x 2}=h_{2}$. Consequently, the form factor $f_{i}$ can be obtained experimentally, as shown in eqn. 5 :

$$
f_{1}=\frac{g_{x c}}{g_{2}}
$$

where $g_{x c}$ is the constant cross-sectional area of an equivalent cylinder of the bole from $2 \mathrm{~m}$ to the top of the tree, $g_{2}$ is the cross-sectional area measured at a height of $2 \mathrm{~m}$, and $f_{\mathrm{i}}$ is the form factor of the bole measured above $2 \mathrm{~m}$ that is obtained experimentally.

Using the volumes of an average tree obtained by the xylometer method and the Smalian + Paraboloid method, as shown in Tab. 1, we calculated what was proposed above (Tab. 4).

From the calculation of the cross-sectional area of the cylinder, the volume of which was equivalent to that obtained above $2 \mathrm{~m}$ by the xylometer method, and knowing that the total height of the tree was $25.67 \mathrm{~m}(\mathrm{~h})$ and the height of the paraboloid was $23.67 \mathrm{~m}\left(h_{2}\right)$, then we have (eqn. 6):

$g_{x c}=\frac{v_{x 2}}{h_{2}}=\frac{0.18185}{23.67}=0.0076827 \mathrm{~m}^{2}$

From a calculation of the base cross-sectional area of the Apollonius paraboloid, we have (eqn. 7):

$g_{2}=\frac{v_{2}}{f_{2} h_{2}}=\frac{0.18397}{0.5(23.67)}=0.0155446 \mathrm{~m}^{2}$

where $g_{2}$ is the cross-sectional area measured at a height of $2 \mathrm{~m}$ on the stem, $v_{2}$ is the volume of the bole measured above 2 $\mathrm{m}, f_{2}$ is the form factor of the bole measured above $2 \mathrm{~m}$ that is obtained experimentally, and $h_{2}$ is the height of the tree measured above $2 \mathrm{~m}$.

Therefore, the average form factor $\left(f_{\mathrm{pe}}\right)$ of a paraboloid with a volume equivalent to that obtained by a xylometer is given by (eqn. 8):

$$
f_{p e}=\frac{g_{x c}}{g_{2}}=\frac{0.0076827}{0.0155446}=0.4942
$$

where $f_{\mathrm{pe}}$ is the average form factor of a paraboloid equivalent to the xylometer volume, $g_{x c}$ is the constant cross-sectional area of an equivalent cylinder of the bole from $2 \mathrm{~m}$ to the top of the tree, and $g_{2}$ is the cross-sectional area measured at a height of $2 \mathrm{~m}$ on the bole.

Hence, the initial proposal of applying the Apollonius paraboloid to the data was validated. However, this approach would not always be appropriate. If a cubic or semicubic paraboloid was applied instead, the 
Tab. 4 - Comparison of bole-volume estimates of an average tree taken from a Eucalyptus urophylla forest stand among different paraboloid forms. $\left(v_{n}\right)$ : neiloid volume obtained by Smalian's method; $\left(v_{2}\right)$ : xylometer volume, or from Smalian, or from a different paraboloid; $\left(v_{\mathrm{xn}}\right)$ : neiloid volume by xylometer below $2 \mathrm{~m} ;\left(f_{\mathrm{i}}\right)$ : paraboloid form factor. Values followed by the same letter did not significantly differ at the $95 \%$ probability level.

\begin{tabular}{|c|c|c|c|c|c|}
\hline \multirow{2}{*}{ Treatment } & \multirow{2}{*}{ n } & \multicolumn{3}{|c|}{ Average volume $\left(\mathrm{m}^{3}\right)$} & \multirow{2}{*}{$f_{i}$} \\
\hline & & $v_{\mathrm{n}}$ & $v_{2}$ & Total & \\
\hline Xylometer & 150 & 0.03555 & 0.18185 & $0.2174^{\mathrm{a}}$ & - \\
\hline Smalian & 150 & 0.03506 & 0.18144 & $0.2165^{\mathrm{a}}$ & - \\
\hline Smalian + Apollonius Paraboloid & 150 & 0.03506 & 0.18397 & $0.2190^{\mathrm{a}}$ & 0.500 \\
\hline$v_{\mathrm{xn}}+$ Apollonius Paraboloid & 150 & 0.03555 & 0.18397 & $0.2195^{\mathrm{a}}$ & 0.500 \\
\hline$v_{x n}+$ Cubic Paraboloid & 150 & 0.03555 & 0.22025 & $0.2558^{c}$ & 0.600 \\
\hline$v_{\mathrm{xn}}+$ Semi-cubic Paraboloid & 150 & 0.03555 & 0.15735 & $0.1929^{b}$ & 0.429 \\
\hline$v_{\mathrm{xn}}+$ Equivalent Paraboloid & 150 & 0.03555 & 0.18184 & $0.2174^{\mathrm{a}}$ & 0.494 \\
\hline
\end{tabular}

Tab. 5 - Volumes obtained for validation using the proposed methodology. $(d)$ : diameter at $2 \mathrm{~m} ;(h)$ : height; $\left(v_{1}\right):$ volume $\left(\mathrm{m}^{3}\right) \leq 2 \mathrm{~m}$ (Smalian); $\left(v_{2}\right)$ : volume $\left(\mathrm{m}^{3}\right) \geq 2 \mathrm{~m}$ to the tip (Smalian); $\left(v_{3}\right)$ : volume $\left(\mathrm{m}^{3}\right) \geq 2 \mathrm{~m}$ to the tip (Apollonius paraboloid); $\left(t v_{1}\right)$ : total volume $\left(\mathrm{m}^{3}\right)$ Smalian (traditional); $\left(t v_{2}\right)$ : total volume $\left(\mathrm{m}^{3}\right)$ paraboloid (proposed).

\begin{tabular}{|c|c|c|c|c|c|c|c|}
\hline Tree & $d(\mathrm{~cm})$ & $h(\mathrm{~m})$ & $v_{1}\left(m^{3}\right)$ & $v_{2}\left(m^{3}\right)$ & $v_{3}\left(m^{3}\right)$ & $t v_{1}\left(m^{3}\right)$ & $t v_{2}\left(m^{3}\right)$ \\
\hline 1 & 6.70 & 14.30 & 0.00742 & 0.02152 & 0.02168 & 0.02893 & 0.02910 \\
\hline 2 & 7.95 & 15.30 & 0.02012 & 0.01962 & 0.02261 & 0.03974 & 0.04273 \\
\hline 3 & 7.95 & 15.90 & 0.01025 & 0.03529 & 0.03312 & 0.04554 & 0.04337 \\
\hline 4 & 11.45 & 24.70 & 0.03052 & 0.09315 & 0.09620 & 0.12367 & 0.12671 \\
\hline 5 & 11.75 & 21.60 & 0.02289 & 0.09792 & 0.09887 & 0.12080 & 0.12176 \\
\hline 6 & 12.04 & 22.30 & 0.02230 & 0.10704 & 0.10743 & 0.12935 & 0.12973 \\
\hline 7 & 12.05 & 23.50 & 0.02476 & 0.11874 & 0.11803 & 0.14350 & 0.14278 \\
\hline 8 & 12.40 & 23.80 & 0.02421 & 0.12726 & 0.12270 & 0.15147 & 0.14691 \\
\hline 9 & 13.05 & 24.50 & 0.02865 & 0.14182 & 0.14196 & 0.17047 & 0.17061 \\
\hline 10 & 13.80 & 24.20 & 0.03017 & 0.14737 & 0.15030 & 0.17754 & 0.18047 \\
\hline 11 & 14.50 & 25.50 & 0.03469 & 0.18151 & 0.18129 & 0.21620 & 0.21599 \\
\hline 12 & 14.50 & 26.20 & 0.03469 & 0.19539 & 0.19023 & 0.23007 & 0.22491 \\
\hline 13 & 14.53 & 24.50 & 0.03355 & 0.16289 & 0.16618 & 0.19643 & 0.19972 \\
\hline 14 & 14.58 & 25.40 & 0.03519 & 0.17913 & 0.18025 & 0.21432 & 0.21544 \\
\hline 15 & 14.59 & 26.10 & 0.03754 & 0.19129 & 0.19262 & 0.22883 & 0.23016 \\
\hline 16 & 14.78 & 25.70 & 0.03715 & 0.18767 & 0.19037 & 0.22482 & 0.22752 \\
\hline 17 & 14.88 & 29.10 & 0.03541 & 0.23071 & 0.22421 & 0.26612 & 0.25962 \\
\hline 18 & 14.90 & 26.30 & 0.03778 & 0.20143 & 0.20015 & 0.23921 & 0.23793 \\
\hline 19 & 14.95 & 25.60 & 0.03496 & 0.19646 & 0.19390 & 0.23142 & 0.22886 \\
\hline 20 & 15.03 & 25.80 & 0.03565 & 0.20123 & 0.20262 & 0.23687 & 0.23827 \\
\hline 21 & 15.30 & 26.80 & 0.03861 & 0.21367 & 0.21491 & 0.25228 & 0.25352 \\
\hline 22 & 16.12 & 29.30 & 0.04203 & 0.25962 & 0.25992 & 0.30164 & 0.30194 \\
\hline 23 & 16.40 & 29.20 & 0.04468 & 0.26931 & 0.26953 & 0.31399 & 0.31421 \\
\hline 24 & 16.78 & 27.10 & 0.04532 & 0.26122 & 0.26405 & 0.30654 & 0.30937 \\
\hline 25 & 17.57 & 29.70 & 0.05032 & 0.31655 & 0.32063 & 0.36686 & 0.37094 \\
\hline 26 & 19.20 & 30.00 & 0.06251 & 0.38638 & 0.39140 & 0.44889 & 0.45991 \\
\hline 27 & 19.50 & 29.40 & 0.06823 & 0.37175 & 0.37701 & 0.43998 & 0.44924 \\
\hline 28 & 21.23 & 32.90 & 0.07183 & 0.51651 & 0.52842 & 0.58835 & 0.60025 \\
\hline
\end{tabular}

(a)

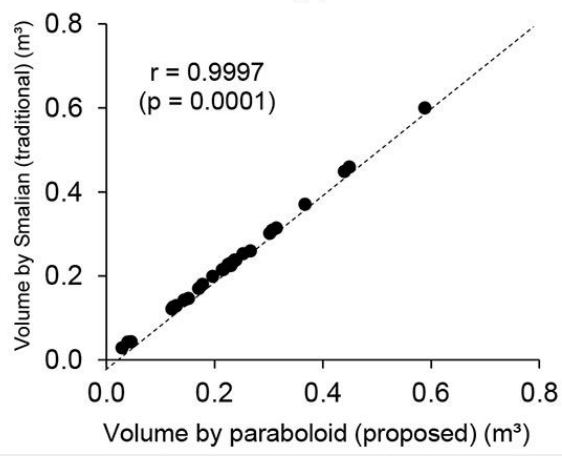

(b)

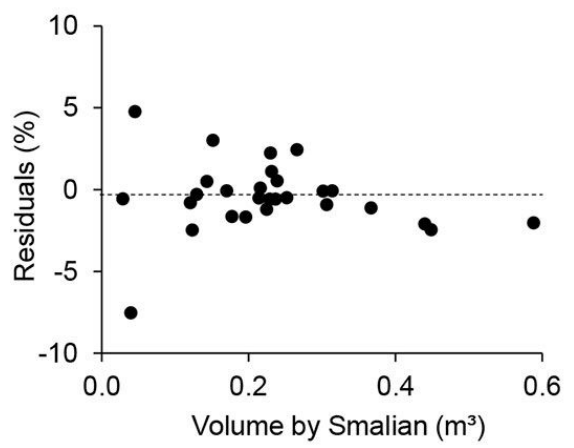

(c)

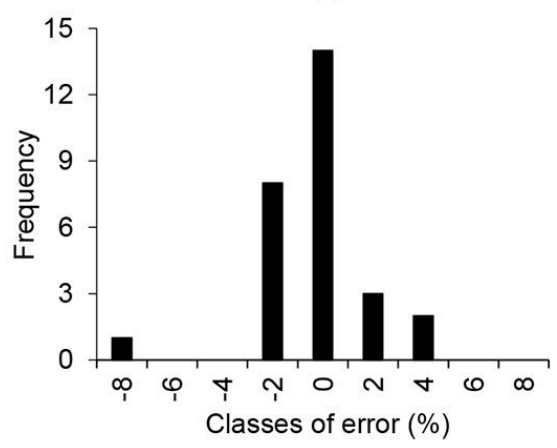

Fig. 5 - (a) Correlations between volumes obtained by the Smalian's method and the proposed paraboloid method. (b) Distribution of residuals. (c) Histogram of residuals. 
results would be statistically different to the parametric value, as it can be noticed from Tab. 4.

In order to validate the methodology proposed, a sample of 28 trees was taken in another E. urophylla forest stand. After calculating the average diameter of this sample, the tree closest to this value, which in this case was the $11^{\text {th }}$ tree of the sample, was identified. The data are presented in Tab. 5 .

The cross-sectional area of the cylinder, whose volume is equivalent to the volume of the paraboloid obtained by Smalian's method, is given by (eqn. 9):

$$
g_{x c}=\frac{v_{2 s}}{h_{t}-2}=\frac{0.18151}{23.5}=0.0077238 \mathrm{~m}^{2}
$$

where $g_{x c}$ is the constant cross-sectional area of an equivalent cylinder of the bole from $2 \mathrm{~m}$ to the top of the tree, $v_{2 \mathrm{~s}}$ is the volume of the bole measured above $2 \mathrm{~m}$ equivalent to the volume of the paraboloid obtained by Smalian's method, and $h_{t}$ is the total height of the tree.

The cross-sectional area of the base of the paraboloid is obtained by (eqn. 10):

$$
\begin{aligned}
g_{2} & =\frac{\pi}{4} d_{2}^{2}=0.7853982(0.1403)^{2}= \\
& =0.0154598 \mathrm{~m}^{2}
\end{aligned}
$$

where $g_{2}$ is the cross-sectional area measured at a height of $2 \mathrm{~m}$ on the stem and $d_{2}$ is the diameter measured at $2 \mathrm{~m}$.

The form factor of the paraboloid to be used for the calculation of the volumes of the remaining sample trees is obtained by:

$$
\begin{aligned}
f_{i} & =\frac{g_{x c}}{g_{2}}=\frac{0.0077238}{0.0154598}= \\
& =0.4996074 \simeq 0.5
\end{aligned}
$$

where $f_{i}$ is the form factor of the paraboloid to be used to calculate the volumes of the remaining trees, $g_{x c}$ is the constant cross-sectional area of an equivalent cylinder of the bole from $2 \mathrm{~m}$ to the top of the tree, and $g_{2}$ is the cross-sectional area measured at a height of $2 \mathrm{~m}$ on the bole.

The form factor for this new sample resulted in a value that was even closer to 0.5 , i.e., the Apollonius paraboloid was appropriate for the calculation of the volumes of the remaining trees. The validation results are presented in Tab. 5 .

The distribution of residuals for the volume obtained by the Smalian's method had errors of between $-7.53 \%$ and $4.75 \%$, with no evidence of bias. The correlation coefficient between the volumes obtained by the Smalian's method and the proposed paraboloid was 0.9997 (Fig. 5).

The analytical solution obtained by using a paraboloid in the second section of the tree above $2 \mathrm{~m}$ supports our first hypothesis. The proposed methodology for finding an appropriate form factor of a paraboloid to be used in the calculation of the volume equivalent to that obtained by a xylometer was efficient and accurate, which supports our second hypothesis.

\section{Conclusions}

The values obtained by traditional scaling using the Smalian's method (destructive) and the Smalian + Paraboloid method (nondestructive) were not statistically different from those obtained by the reference method (xylometer); therefore, they are equivalent.

The adjustment of the Schumacher \& Hall model with data obtained by compatible methods (Xylometer, Smalian, and Smalian + Paraboloid) enabled to obtain accurate equations for estimating tree volume in a E. urophylla stand.

The Smalian + Paraboloid method (without tree felling) would improve data collection and reduce the cost of the forest inventory activities that are conducted in forest plantations. Such method can obtain tree volumes in situations where scaling (destructive) is impracticable.

Updating the volumetric estimators for older E. urophylla forest stands would be simple and inexpensive, and of major importance for ensuring the accuracy of volumetric estimators for old trees.

The use of an equivalent paraboloid to express the mean volume of trees sampled by the xylometer or traditional Smalian's method maximizes the accuracy of volume estimation in stands of E. urophylla.

The methodology proposed in this study for E. urophylla is suitable also for other species, given the high uniformity and homogeneity of forest plantations in Brazil.

\section{Acknowledgments}

The authors would like to thank the Mixed Cooperative of Araguaia Valley (COMI$\mathrm{GO}$ ) for financial support, providing the study site, and support during the field measurements.

EPM designed and setup the study. EPM, GBA, GTOSA, and SPN analyzed the data and wrote the paper. AVR and RSP reviewed the paper.

\section{References}

Akindele SO, LeMay VM (2006). Development of tree volume equations for common timber species in the tropical rain forest area of Nigeria. Forest Ecology Management 226: 41-48. doi: 10.1016/j.foreco.2006.01.022

Akossou AYJ, Arzouma S, Attakpa EY, Fonton NH, Kokou K (2013). Scaling of teak (Tectona grandis) logs by the xylometer technique: accuracy of volume equations and influence of the log length. Diversity 5: 99-113. - doi: 10.3390/d5 010099

Andrade VCL, Souza AL, Calegário N (2014). Equações segmentadas de perfil do tronco geradas a partir da equação que descreve sólidos geométricos [Segmented trunk profile equations generated from the equation for obtaining geometric solids]. Pesquisa Florestal Brasileira 34: 285-301. [in Portuguese] - doi: 10.4336/ 2014.pfb.34.80.654

Azevedo GB, Sousa GTO, Barreto PAB, Conceição Júnior $V$ (2011). Estimativas volumétricas em povoamentos de eucalipto sob regime de alto fuste e talhadia no sudoeste da Bahia [Vol- umetric estimates in eucalypt plantation under regime of high forest and coppice in the southwest of Bahia, Brazil]. Pesquisa Florestal Brasileira 31: 309-318. [in Portuguese] - doi: 10.4336/ 2011.pfb.31.68.309

Batista JLF, Couto HTZ, Silva Filho DF (2014). Quantificação de recursos florestais: árvores, arvoredos e florestas [Quantification of forest resources: trees, groves and forests] ( $\left.1^{\text {st }} \mathrm{edn}\right)$. Oficina de Textos, São Paulo, Brasil, pp. 384. [in Portuguese]

Breymann K (1868). Anleitung zur holzme $\beta$ kunst, waldertrags bestimmung und waldwertberechnung [Guidance for the art of measuring wood, determining forest yield and calculating forest value]. Wien, Austria, pp. 644. [in German]

Draper NR, Smith H (1998). Applied regression analysis ( $\left.3^{\text {rd }} \mathrm{edn}\right)$. Wiley-Interscience, New York, USA, pp. 736.

EMBRAPA (2013). Sistema brasileiro de classificação de solo [Brazilian soil classification system] (3 ${ }^{\text {rd }}$ edn). Embrapa Solos, Brasília, Brazil, pp. 342. [in Portuguese]

Figueiredo Filho A, Machado SA, Carneiro MRA (2000). Testing accuracy of log volume calculation procedures against water displacement techniques (xylometer). Canadian Journal of Forest Research 30: 990-997. - doi: 10.1139/xoo006

Grosenbauch LR (1966). Tree form: definition, interpolation, extrapolation. Forestry Chronicle 42: 444-457. - doi: 10.5558/tfc42444-4

Hammer O, Harpe ATD, Ryan PD (2001). PAST: paleontological statistics software package for education and data analysis. Palaeontologia Electronica 4: 1-9.

Hohenadl W (1922). Neue grundlagen der holzmessung [New foundations of wood measurement]. Forstwissenschaftliches Centralblatt 44: 184-194. [in German] - doi: 10.1007/BF01773849 Husch B, Miller IC, Beers TW (1983). Forest Mensuration. J. Wiley, New York, USA, pp. 402.

Höjer AG (1903). Tallens och granens tillväxt [Pine and spruce growth]. Bihang till Fr. Loven. Om våra barrskogar, Stockholm, Sweden, pp. 62. [in Swedish]

IUSS Working Group WRB (2010). A framework for international classification, correlation and communication. World Soil Resources Reports no. 103, Word Reference Base for Soil Resources, Food and Agriculture Organization of the United Nations, Rome, Italy, pp. 145.

Kozak A, Munro DD, Smith JHG (1969). Taper functions and their applications in forest inventories. Forestry Chronicle 45: 278-283. - doi: 10.5558/tfc45278-4

Larson PR (1963). Stem form development of forest tree. Society of American Foresters, Washington, DC, USA, pp. 42.

Liu CJ (1980). Log volume estimation with spline approximation. Forest Science 26: 361-369. doi: 10.1093/forestscience/26.3.361

Loetsch F, Zoehrer F, Haller KE (1973). Forest Inventory ( $2^{\text {nd }}$ edn). BLV, München, Germany, pp. 469.

Machado SA, Figueiredo Filho A (2014). Dendrometria [Dendrometry] (2 ${ }^{\text {nd }}$ edn). UNICENTRO, Guarapuava, Brasil, pp. 316. [in Portuguese]

Machado SA, Urbano E, Conceição MB, Figuei- 
redo Filho A, Figueiredo DJ (2004). Comparação de modelos de afilamento do tronco para diferentes idades e regimes de desbaste em plantações de Pinus oocarpa Schiede [Comparison of taper functions for different ages and thinning regimes in Pinus oocarpa plantations]. Boletim de Pesquisa Florestal 48: 41-64. [in Portuguese]

Machado SA, Urbano E, Conceição MB (2005). Comparação de métodos de estimativa de volume para Pinus oocarpa em diferentes idades e diferente regimes de desbastes [Comparison of volume estimation methods for Pinus oocarpa at different ages and thinning regimes]. Pesquisa Florestal Brasileira 50: 81-98. [in Portuguese]

Machado SA, Téo SJ, Urbano E, Figura MA, Silva LCR (2006). Comparação de métodos de cubagem absolutos com o volume obtido pelo xilômetro para bracatinga (Mimosa scabrella Bentham) [Comparison of absolute scaling methods with the volume obtained by the xylometer method for bracatinga (Mimosa scabrella Bentham)]. Cerne 12: 239-253. [in Portuguese]

Machado SA, Figura MA, Silva LCR, Téo SJ, Stolle L, Urbano E (2008). Modelagem volumétrica para bracatinga (Mimosa scabrella) em povoamentos da Região Metropolitana de Curitiba [Volumetric modeling for bracatinga (Mimosa scabrella) in bracaringa stands in Curitiba Metropolitan Region]. Pesquisa Florestal Brasileira 56: 17-29. [in Portuguese]

Murta Júnior LS, Oliveira MLR, Nogueira GS, Castro RVO, Pelli E, Silva EA (2015). Estimation of total volume of Eucalyptus through measurements at the tree base. Australian Journal of Basic and Applied Sciences 9: 134-141.

Piñeiro G, Perelman S, Guerschman JP, Paruelo JM (2008). How to evaluate models: observed vs. predicted or predicted vs. observed? Ecological Modelling 216: 316-322. - doi: 10.1016/j.ecol model.2008.05.006
Preußner K (1974). Eine neue schaftkurvengleichung und ihre anwendung [A new solution for taper curve equations and its application]. Wissenschaftliche Zeitschrift 23: 305-309. [in German]

Prodan M (1965). Holzmesslehre [Learning to measure trees]. J.D. Sauerländer's Verlag, Frankfurt, Germany, pp. 644. [in German]

Péllico Netto S, Brena DA (1997). Inventário florestal [Forest inventory]. Editorado pelos autores, Curitiba, Brazil, pp. 316. [in Portuguese]

Riecke F (1840). Über die Berechnung des körperlichen Inhalts und beschlagener Baumstämme [On the calculation of the corp content and evaluation of tree stems]. Stuttgart, Germany, pp. 75. [in German]

Roiko-Jokela P (1976). Die schaftformfunktion der fichte und die bestimung der sortimente am stehenden baum [The taper function for the spruce and the determination of the assortments at the standing tree]. Eidgenössische Anstalt für das Forst Versuchswesen, Zürich, Switzerland, pp. 52. [in German]

Row C, Guttenberg S (1966). Determining weight-volume relationship for saw logs. Forest Products Journal 16: 39-47.

Schiffel A (1902). Die kubierung von rundholz aus zwei durchmessern und der lange [The volume evaluation of tree stem with two diameters and the length]. Verschswesen Österreichs, Wien, Austria. pp. 148. [in German]

Schröder T, Pereira LD, Hofiço NSA (2013). Comparação de métodos de estimativa de volume total para Eucalyptus grandis W. Hill ex Maiden [Comparing methods for total volume estimation for Eucalyptus grandis W. Hill ex Maiden]. Floresta e Ambiente 20: 480-486. [in Portuguese] - doi: 10.4322/floram.2013.041

Schuberg K (1891). Formzahlen und massentafeln für die weißtanne [Form factors and volume tables for spruce]. Verlag Paul Parey, Berlin, Germany, pp. 165. [in German]

Schumacher FX, Hall FS (1933). Logarithmic expression of timber-tree volume. Journal of Agricultural Research 47: 719-734.

Schöpfer W (1966). Automatisierung der massen-, sorten- und wertberechnung stehender waldbestände [Automation of the mass, species and value calculation of standing forest stands] ( $21^{\text {st }}$ edn). Landesforstverwaltung Baden-Württemberg, Stuttgart, Germany, pp. 108. [in German]

Simony O (1904). Über Form zahlengleichungen und deren forst-mathematische verwertung [About form numerical equations and their forest-mathematical utilization]. Wien, Austria, pp. 54. [in German]

Siqueira Neto M, Piccolo MC, Costa Junior C, Cerri CC, Bernoux M (2011). Emissão de gases do efeito estufa em diferentes usos da terra no bioma Cerrado [Greenhouse gas emission caused by different land-uses in brazilian Savannah]. Revista Brasileira de Ciência do Solo 35: 63-76. [in Portuguese] - doi: 10.1590/S010006832011000100006

Smalian HL (1837). Beitrag zur holzmeßkunst [Contribution to the art of measuring wood]. Verlag Löffler, Stralsund, Germany, pp. 87. [in German]

Soares CPB, Silva GF, Martins FB (2010). Influence of section lengths on volume determination in Eucalyptus trees. Cerne 16: 155-162. - doi: 10.1590/S0104-77602010000200006

Soares C, Paula Neto F, Souza A (2011). Dendrometria e inventário florestal [Forest mensuration and forest inventory] ( $2^{\text {nd }}$ edn). Editora UFV, Viçosa-MG, Brasil, pp. 272. [in Portuguese] Soil Survey Staff (2010). Keys to soil taxonomy ( $11^{\text {th }}$ edn). USDA, Washington, pp. 338. [online] URL: http://eprints.stiperdharmawacana.ac.id/ 118/1/[Soil_Survey_Staff]_Keys_to_Soil_Taxono my(BookFi).pdf

Spurr SH (1952). Forest Inventory. The Ronald Press Company, New York, USA, pp. 476.

Van Laar A, Akça A (2007). Forest mensuration. Springer, Dordrecht, The Netherlands, pp. 383. 